\title{
Site Selection Criteria for Sports Retail Sector: Istanbul Case
}

\author{
Tolga Kayacan, Funda Yirmibeşoğlu \\ Department of Urban and Regional Planning, Istanbul Technical University, Istanbul, Turkey \\ Email: tolga_kayacan@yahoo.com
}

How to cite this paper: Kayacan, T., \& Yirmibeşoğlu, F. (2017). Site Selection Criteria for Sports Retail Sector: Istanbul Case. Current Urban Studies, 5, 290-304. https://doi.org/10.4236/cus.2017.53016

Received: June 11, 2017

Accepted: July 28, 2017

Published: July 31, 2017

Copyright $\odot 2017$ by authors and Scientific Research Publishing Inc. This work is licensed under the Creative Commons Attribution International License (CC BY 4.0).

http://creativecommons.org/licenses/by/4.0/

\section{(c) (i) Open Access}

\begin{abstract}
The retail sector has been greatly developing in Turkey, especially with the addition of foreign investments in the last few years, which has resulted in a considerable increase in the number of stores. This increase is also evident in the number of stores in sports retail, as is the case in other sub-sectors of retail. The aim of this study is to determine what decisions and criteria are taken into consideration in the sports retail sector regarding the selection of store locations. With this aim in mind, first a survey was conducted and given to customers, the most important component of retail. Second, in order to determine the sporting habits of customers, another survey study was done with users of sports centers, and the results of these two studies were considered together. The third survey study was done with the employees of sports retail stores to see if their points of view supported the results of the first two surveys. According to the results of the surveys, the most convenient locations for the sports retailers seem to be shopping malls because they provide various facilities, are easily accessible and provide a wide range of stores which have almost every product one would look for. And also like other retailers, sports retail stores prefer locations that are easily accessible and that can be reached by great numbers of people.
\end{abstract}

\section{Keywords}

Retail Sector, Location, Site Selection, Sports Retail, Store

\section{Introduction}

Retail is almost as old as humanity itself; the history of retail dates back to bartering for goods in the first ages. Having started with the set up of barter-based open markets, retail underwent a transformation with the invention of money and with settled life. As a result of that transformation, retail areas started to 
become closed areas, like caravanserais on trade routes and big bazaars where the same type of goods is sold. By the 18th century, stores started to emerge. Department stores came along by the 19th century, and chain stores emerged by the 20th century. Shopping centers that emerged in USA as of 1950 are now important symbols of retail all over the world.

Site selection was formalized in the 1940s and 1950s through a number of important U.S. government projects. After these works, site selection was spread to all sectors and each sector started to specify its own site-selection criteria according to the scope of its business activities. Retail sector selects locations that are easily accessible and where it can offer its products to a maximum number of customers. Thus, competition has become one of the most overriding concerns for retail sector.

In the economic conditions of our time, entrepreneurs act on a "benefit-costprofit"-basis and think more carefully about site selection with expectations of return in the shortest possible period of time. That is why the general tendency turns out to be working in areas of dense economic activities and avoiding underdeveloped areas (Cemalcilar et al., 1976).

Recently, as a consequence of the current economic conditions in Turkey, most of the retail companies have started to reduce the number of their stores. Sports retail sector has also been affected by these conditions; sports retail companies prefer to close down their stores on commercial streets and channel their investments into shopping centers. Some companies that are known to prefer locations out of shopping centers have also started to prefer shopping centers for their investments.

The aim of this study is to determine the site selection criteria of sports retail companies and the locations they prefer for their stores. In the scope of the study, surveys are done to specify if the location choices and criteria match with the needs of the users.

\section{Site Selection}

Theodor Sabathil's 1969 dissertation is considered one of the earliest in-depth studies in the area of international site selection. Therein, Sabathil largely focuses on country selection, which is part of the site selection process. Within this regard, Sabathil has compiled a comprehensive catalogue of site factors and proposed a theoretical approach to site selection; yet, he does not provide great detail about the approach nor does he take any legal, natural, or cultural site factors into consideration. However, he discusses in particular company-specific framework conditions and psychological factors (Glatte, 2015).

The dissertation submitted in 1980 by Peter Tesch constitutes another milestone in the further development of international site theory. Tesch combines theories of international trade and investment with site theories. He is the first to include country-specific framework conditions in his analysis. The main basis for his comments on the various types of internationalization is location-specific 
competitive advantages. Within this framework, Tesch developed a catalogue of criteria for international site decisions grouped under three categories (Tesch, 1980):

1) Site factors affecting all company activities

2) Availability and costs of the site factors impacting the production factors

3) Turnover-related site factors

Thomas Goette's 1994 study tries to classify important international site factors and to structure the process of international site selection. Goette distinguishes between economic site conditions (sales potential, competitive conditions, infrastructure and transportation costs, labor, monetary conditions), political site conditions (tax legislation, environmental protection, institutional market entry barriers, support of business, political risks), cultural site conditions (differences in language, mentality, religion, and the lack of acceptance of foreign companies), and geographical site conditions (climate, topography). This study again demonstrates that an attempt to cover all aspects will result in loss of quality as all factors were not or could not be taken into consideration. Goette also theorizes that, in particular, industrial site decisions within companies are usually once-off and division-related decision-making processes. Based on this, Goette assumes a relatively low learning curve, and hence little potential for improvement for subsequent projects (Goette, 1994).

To avoid conceptual confusion and to explain the topic in full, it is important that the factors to be considered for site selection must be based on the business activities of the company. In other words, site selection factors must not be considered as static and the same for each business activity; factors will vary for different activities (Uygun, 1990).

Factors that affect site selection are not only complicated, but also related closely to each other. Anything that outflanks the production (or marketing) activities in a certain place (especially outflanks in costs) can be considered as site selection factors (Uygun, 1990).

Although site selection factors vary for each business activity, according to Cemalcilar et al. (1976), 4 main factors are considered for site selection for any company (Table 1).

There are several methods for site selection. Companies can choose different site selection methods in consideration of their business activities, their target customers or transportation costs of their products. In Table 2, methods that are frequently used are presented with short explanations (Kayacan, 2017).

Many theories have been developed about site selection. They attempted to explain the site selection of companies with scientific facts. Although these theories have received considerable support, they have also been challenged and criticized by some researchers, some of whom proposed counter theories. These theories have undergone a lot of changes in time, but some of them still remain valid today. In Table 3, main site selection theories are summarized (Kayacan, 2017). 
Table 1. Site selection factors.

\begin{tabular}{|c|c|}
\hline \multicolumn{2}{|r|}{ Site Selection Factors } \\
\hline Economic Factors & $\begin{array}{c}\text { Raw materials, labor, energy, transportation, } \\
\text { work force and distance to market }\end{array}$ \\
\hline Natural Factors & $\begin{array}{c}\text { Climate and topography, height, seismic zones, } \\
\text { humidity levels, wind conditions }\end{array}$ \\
\hline Social Factors & $\begin{array}{l}\text { Places where workers can socialize after work, } \\
\text { companies that have environmental effects }\end{array}$ \\
\hline $\begin{array}{c}\text { Psychological, } \\
\text { Physiological } \\
\text { and Political Factors }\end{array}$ & $\begin{array}{l}\text { Personal conditions of the entrepreneur, state policies, } \\
\text { incitements, facilities that care about human health and psychology }\end{array}$ \\
\hline
\end{tabular}

Source: Kayacan, 2017.

Table 2. Site selection methods.

Site Selection Methods
$\begin{gathered}\text { The company determines the factors that are crucial for it and } \\ \text { chooses from different location alternatives the one which has } \\ \text { the highest average points according to the importance of factors. }\end{gathered}$
The company chooses the location according to distance
and goods to be sent, considering its existing facilities
Conter of Gravity
$\begin{array}{r}\text { The company considers work force, transportation, energy, } \\ \text { land, construction costs and chooses the location accordingly. } \\ \text { Another version of Center of Gravity method. The company } \\ \text { chooses the location according to other companies. } \\ \text { The company chooses the location comparing } \\ \text { its income and expenses. }\end{array}$
Aransportation Model $\quad \begin{array}{r}\text { The company chooses a location where the } \\ \text { total transportation costs are at a minimum. }\end{array}$

Table 3. Site selection theories.

\begin{tabular}{|c|c|}
\hline \multicolumn{2}{|r|}{ Site Selection Theories } \\
\hline Central Place Systems & $\begin{array}{l}\text { It is based on a single center and a flat land. Consumers } \\
\text { choose the shortest distance and shop with a single purpose. }\end{array}$ \\
\hline Bid Rent Theory & $\begin{array}{l}\text { Companies can pay higher rents and increase the value of the } \\
\text { land to attract more customers and increase competition. }\end{array}$ \\
\hline Retail Gravitation & $\begin{array}{l}\text { Two big cities attract the trade from } \\
\text { a small town to themselves. }\end{array}$ \\
\hline $\begin{array}{l}\text { Multipurpose Shopping } \\
\text { and Retail Agglomeration }\end{array}$ & $\begin{array}{l}\text { A theory showing that customers can prefer longer distances } \\
\text { in order to find the product or service they are looking for. } \\
\text { Consumers also go out for multipurpose shopping. }\end{array}$ \\
\hline Spatial Interaction and & It states that retail locations and their \\
\hline Competing Destinations & environments attract customers and affect their choices. \\
\hline
\end{tabular}




\section{Sports Retail Sector and Site Selection}

Today sports is accepted as an important service sector with its protective and improving effects on personal and social health. Also, becoming a profitable marketing tool with the effect of mass communication devices and media, sports is not only a show and entertainment activity for large masses but also an attractive economic activity field for entrepreneurs. Sports is a research topic for business management and sports business management with its dimensions of service production, commodity production, and consumption (Can et al., 2000).

Sports retail sector has remarkably developed in a short period of time. Although sports and recreational activities have long been part of our lives, the sector has experienced an unprecedented development in the last 30 years. This development has been both vertical and horizontal. Horizontal development contains addition of new markets, new products, and new professions. Sports market research companies can be given as an example. Vertical development is seen as the advancement of existing markets and products. An example for vertical development is the increase in the number of women athletes in basketball and volleyball.

Today's global sports industry is worth between $€ 350$ billion and $€ 450$ billion ( $\$ 480$ - $\$ 620$ billion), according to a recent A.T. Kearney study of sports teams, leagues, and federations. This includes infrastructure construction, sporting goods, licensed products and live sports events. Global sports industry is growing much faster than national gross domestic product (GDP) rates around the world. And the global sports value chain-its size, makeup and revenues-has a significant growth potential for the future (AT Kearney, 2011).

In Turkey, sports activities are managed and maintained by governmental institutions as part of service sector, whereas production and consumption dimensions seem to appeal more to private corporations. However, private sector seems to be noncommittal for the sports as part of service sector since the socio-economic and cultural levels of Turkish society and the demand for sports services are not attractive enough for their interest. Because of these reasons, a large part of society is waiting for the government to provide sports services for them. But the departments responsible for sports services are unable to meet the demands because of lack of financial resources and other reasons (Devecioğlu, 2005).

Being one of the most dynamic sectors of Turkish economy with its contribution to employment and size of its turnover, retail sector has grown by $9 \%$ in 2015 and reached a volume of 663 billion TRY. The growth ratio for 2016 is expected to be $11 \%-12 \%$. As a sub-sector of retail, clothing retail is expected to surpass 150 billion TRY by the end of 2016, with a growth of $10 \%$

(Url-1, 2016).

One of the most dynamic sub-sectors of retail is sports retail. As a result of increased consciousness of healthy living, the number of people in Turkey who practices sports is increasing every day. Therefore, the sports retail sector has a 
volume of 6 billion TRY and growing by $6 \%$ per year. In addition to the companies desiring to increase the number of their stores, new ambitious brands entering the market is expected to bring about a higher growth rate for the sports retail (Url-1, 2016).

The highest share in the total revenues of sports retail belongs to sports shoes, with a market share of approximately $50 \%$. As far as personal shopping rates are concerned, males are leading with a share of $65 \%$. As for sold products, football products have a share of $28 \%$, followed by basketball products with a share of $5 \%$. The highest number of products is sold in Istanbul, followed by Antalya (Çambel, 2016).

In Table 4, the number of existing stores and targets of sports retailers in Turkey are presented (Url-1, 2016).

When we examine the types of sports retail stores in Turkey, we come across with some types, even though there is no official classification. These types can be collected under two main categories (Kayacan, 2017):

1) Stores inside a mall

2) Outdoor stores

Stores inside a mall can be put in two categories:

- Stores that have no connection with outside: This type can be explained as stores that have no relation and no direct access from outside the mall. It is not possible to enter the store without entering the shopping mall. Operating hours of the store must be matching with operating hours of the mall. It is impossible for the store to accept customers out of the operating hours of the mall.

- Stores that have their own entrance: These stores have their own entrance, independent from the entrance of the mall. With the permission of the mall, these stores can accept customers out of the operating hours of the mall, especially on special days. The biggest problem about these stores is the security

Table 4. Number of existing stores and targets of sports retailers in Turkey.

\begin{tabular}{lcccc}
\hline & Brand & $\begin{array}{c}\text { \# of } \\
\text { Existing Stores }\end{array}$ & $\begin{array}{c}\text { Target by the } \\
\text { end of 2016 }\end{array}$ & Long Term Target \\
\hline $\mathbf{1}$ & Adidas & 205 & 212 & - \\
$\mathbf{2}$ & Hummel & $122^{*}$ & $150^{* *}$ & $\begin{array}{c}300 \text { stores in 3 years, } \\
100 \text { stores abroad }\end{array}$ \\
$\mathbf{3}$ & Sportive & 38 & 42 & - \\
$\mathbf{4}$ & Puma & 35 & 37 & 50 stores in 5 years \\
$\mathbf{5}$ & Olgarlar & 32 & 38 & 60 stores in 3 years \\
$\mathbf{6}$ & Decathlon & 20 & 22 & 50 stores in 5 years \\
$\mathbf{7}$ & Skechers & 14 & 17 & 40 stores in 3 years \\
$\mathbf{8}$ & Under Armour & 3 & 9 & 50 stores in 5 years \\
\hline
\end{tabular}

$\left({ }^{*}\right): 2$ abroad $\left.{ }^{* *}\right)$ : 15 abroad. 
issue. Since the store can be accessed from both outside and inside the mall, customers can enter the store without passing through the security checkpoints at the mall entrance, and go directly inside the mall. Because the store itself does not have a security checkpoint, mall managements are not generally willing to allow such stores in the mall.

- Stores that have their own entrance can also be on the ground floor of an office block, a business center or a hotel. Such use is called a "mix-use" project. These stores also have their own entrance, independent from the main entrance of the building. They are different from those in the malls in that such stores usually do not have access from inside the building; yet, these stores also must follow the building management rules.

Outdoor stores can be categorized as street stores and stand-alone stores:

- Street stores: These stores are positioned on the streets that have dense pedestrian and vehicle traffic, and mostly are on the ground floor of the buildings, the upper floors of which are in residential or office use. The operating hours of the store depend on the owner's or manager's own choice. Stores located under a building, in some cases, need to have permission for some actions from the building management. To illustrate, cafes or restaurants need to have permission to utilize the outside area of the building for their own use, or supermarkets need permission to have booths outside the store.

- Stand-alone stores: These stores can be located in retail parks, where each company has its own building, and can also be located on a self-owned parcel. In retail parks, stand-alone stores stand alone just physically-speaking; they must follow the rules of the retail park. They have to follow the operating hours of the retail park. Stand-alone stores on a self-owned parcel are completely independent. Like street stores, they can self-regulate their own operating hours. If the land is rented, the company has the advantage to discuss with the land owner during the construction of the store, and build the store according to its own criteria. The only restrictions in this case would be the plans set by the municipality of the settlement. If the company owns the land, there will not be any owner-related restrictions.

In some other countries, some sports retail companies prefer to have their own stores on a self-owned parcel or their own stand-alone stores in a retail park. One of the most important reasons for this is the shopping habits of the customers. Companies that invest in sports and sell sports goods offer services only as a destination store. Destination stores can be defined as the stores where people make a special trip to come to (Kayacan, 2017).

Another reason for choosing a stand-alone store is the advantage of having the option to expand the store, in cases of having a very high turnover per square meter and receiving more and more customers every day. Considering such an opportunity with stand-alone stores, projections and planning must be made accordingly during the project phase.

Companies that prefer stand-alone stores on a parcel have the chance to design their own identity for their stores. Stores that have a certain concept remain 
in the memory of customers and no matter which store of the company customers choose, they do not feel estranged. Street stores or stores in malls can also have their own concept but stand-alone concepts have a better advantage. Besides, financial planning is easier in this case and costs might be reduced.

\section{A Field Study for Site Selection of Sports Retail Sector: Istanbul Case}

In this section, what criteria is used by the sports retail companies in the most populated city of Turkey, Istanbul for choosing store locations and whether or not these criteria are in line with the needs of customers will be investigated.

\section{Scope and Method of Research}

The scope of the study comprises the customers of the sports retail stores, gym and fitness center users, and employees of the sports retail stores. The study is designed as a survey and 463 surveys are conducted with the store customers, 360 surveys with gym and fitness center users, and another survey is given to employees of 27 different stores. The questionnaire of the first survey includes questions as follows:

- Why the customers choose that store,

- How often they visit the store,

- How long it takes them to reach the store,

- From where they come to the store and where they go after,

- What means of transportation they use to reach the store, and

- Their monthly income.

Similar questions are asked to gym and fitness center users. For the employees of the stores, the questions include:

- When the store was opened,

- The reason why they chose that particular location,

- Whether they are happy with the location or not,

- The profile of their customers,

- If they think that mall stores have an advantage over street stores, or vice versa.

Data collected from the surveys are examined with correlation analysis and cross tabulation analysis. With the help of these data, some results are obtained to help sports retail companies choose the location for their stores.

On Figure 1, local sports retail stores which are registered to Istanbul Chamber of Commerce before 1980 until our day can be seen. The number of stores opened especially after 2010 stand out. On Figure 2, corporate sports retail stores currently operating inside the borders of Istanbul can be seen.

\section{Findings}

Survey results show that the profile of the customers using fitness centers/ gyms is mainly young (between ages 25 and 34 ), highly educated (75\% with a university degree minimum) and middle and high income level (3000+ TRL monthly income). Same profile can be seen in sports retail store customers. 


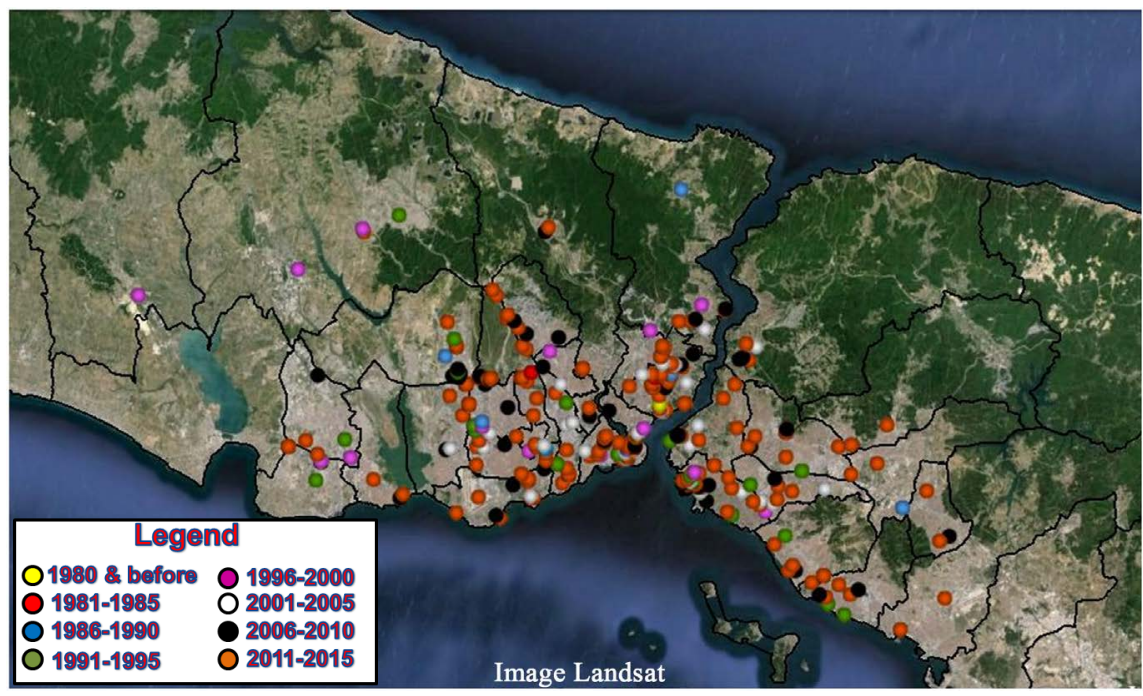

Figure 1. Local sports retail stores in Istanbul registered to The Chamber of Commerce according to years.

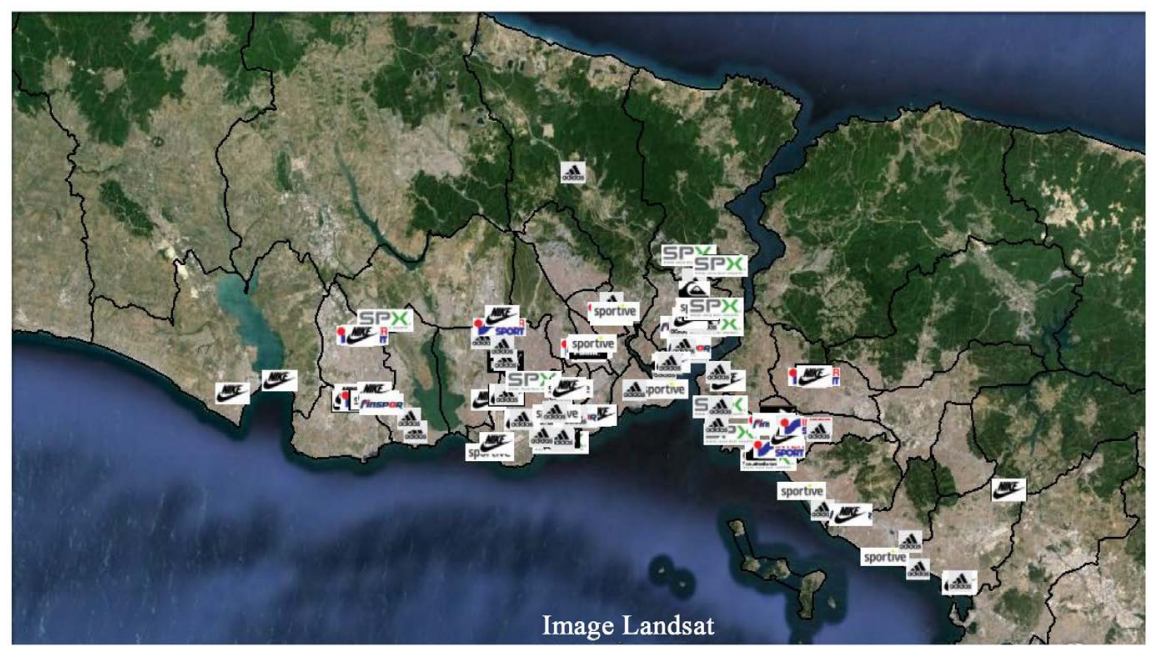

Figure 2. Corporate sports retail stores currently operating within the borders of Istanbul. Source: Kayacan, 2017.

According to the results of the surveys, the first reason why customers choose a particular store is the quality of products, with a rate of $49 \%$. The second one is to find every item one looks for, with a rate of $46 \%$, followed by "close to my home/work place" with a rate of $37 \%$ (multiple answers are accepted). $52 \%$ of the customers stated that they visit the sports store more than 5 times per year. $56 \%$ of the customers spend a maximum of 20 minutes to reach the store. $83 \%$ of the customers come to the store from their homes, and they go back their homes after shopping. $62 \%$ stated that they use private cars to reach the store, followed by public transportation with a rate of $25 \%$. The majority of customers (26\%) have a monthly income over 5000 TRL. Similar results have been obtained from the surveys given to gym and fitness center users (Table 5). 
Table 5. Findings of surveys.

\begin{tabular}{ccc}
\hline & Stores & Gym/Fitness Center \\
Reason of visit & - Product quality & Close to home \\
& - Find everything needed & - Variety of sports \\
Visit frequency & More than 5 times per year & Minimum twice a week \\
Time spent to travel & Maximum 20 minutes & Maximum 20 minutes \\
Location they come & & Home \\
from and they will go to & & Work and home \\
Aducation level & Between 25 and 34 & Between 25 and 34 \\
Income level & University & University
\end{tabular}

In the results of store employee surveys, it can be seen that most of the stores are opened after 2006. Among the reasons for selection of the location are customer profile, high numbers of customers, location, and the prestige of the mall. $89 \%$ of the employees stated that they are happy with the location of the store. $67 \%$ of the customers are middle/upper-middle-class customers. $89 \%$ of the employees think that it is better for the store to be in a mall than to be on a street.

When we examine the overall results of the surveys, we can say that young population in Istanbul visits gym/fitness centers at least twice a week. They prefer to visit centers close to their homes/workplaces, centers that are within a maximum distance of 20 minutes. Even though they are loyal to the centers they visit, they can choose other centers if they cannot find what they are looking for. But most of the customers said they are happy with the centers they use for sports activities. The equipment that is used in fitness centers is bought from well-known corporate sports retail stores.

Regarding the results of the surveys, it can be stated that the majority of those who shop from corporate sports retail stores are young women. Of all the reasons for choosing a particular store, the most significant factors are found to be product quality and product range. For these reasons customers can travel distances more than 30 minutes, and according to the quality and range of products, they can shop from different stores and brands. Mostly private cars are used for transportation and customers travel between their homes and the store. Stores are visited a minimum of 3 times a year for the needs.

According to the employees of the stores, the high number of customers and the income levels of customers are the main reasons that determine the choice of a store's location. For the famous companies, where exactly the store is located in the mall is not so important; still, they prefer to avoid the locations that have low visibility and accessibility. The floors through which customers enter the mall are said to have the highest advantage. When we consider the fact that customers in Turkey have a tendency to shop from malls, it can be stated that choosing a location within a mall will provide a higher advantage. 
When we consider the catchment area of a sports retail store according to results of the surveys, we find out the results as seen on Figure 3 and Figure 4, with travel distances of 10, 20 and 30 minutes, both by car and by walking.

As can be understood from the figures, the possibility of transportation by car increases the potential number of customers. But in Istanbul, one of the biggest problems considering transportation by car is the parking issue. Therefore, customers prefer shopping locations where they can easily park their cars. Customers going for shopping in their private cars usually prefer malls since they have their own parking lots. Street stores are locations mostly preferred by customers who go shopping on foot.

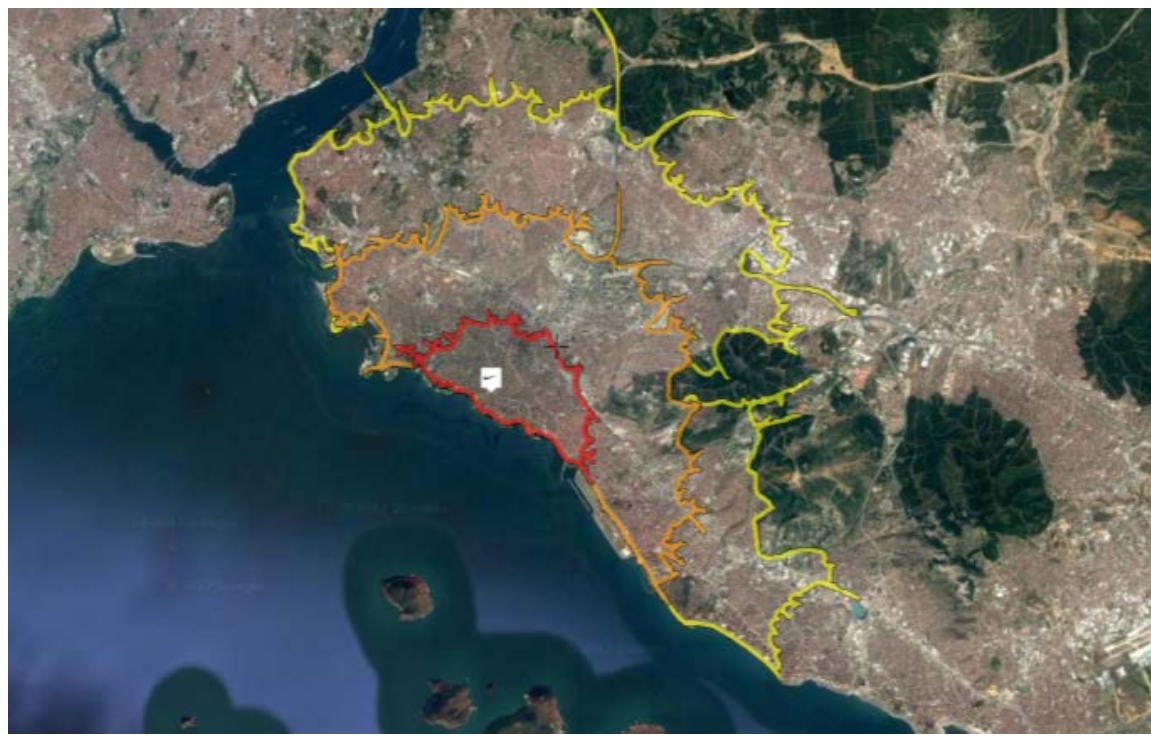

Figure 3. Travel distances of 10 (red), 20 (orange) and 30 minutes (yellow) by car for the chosen store.

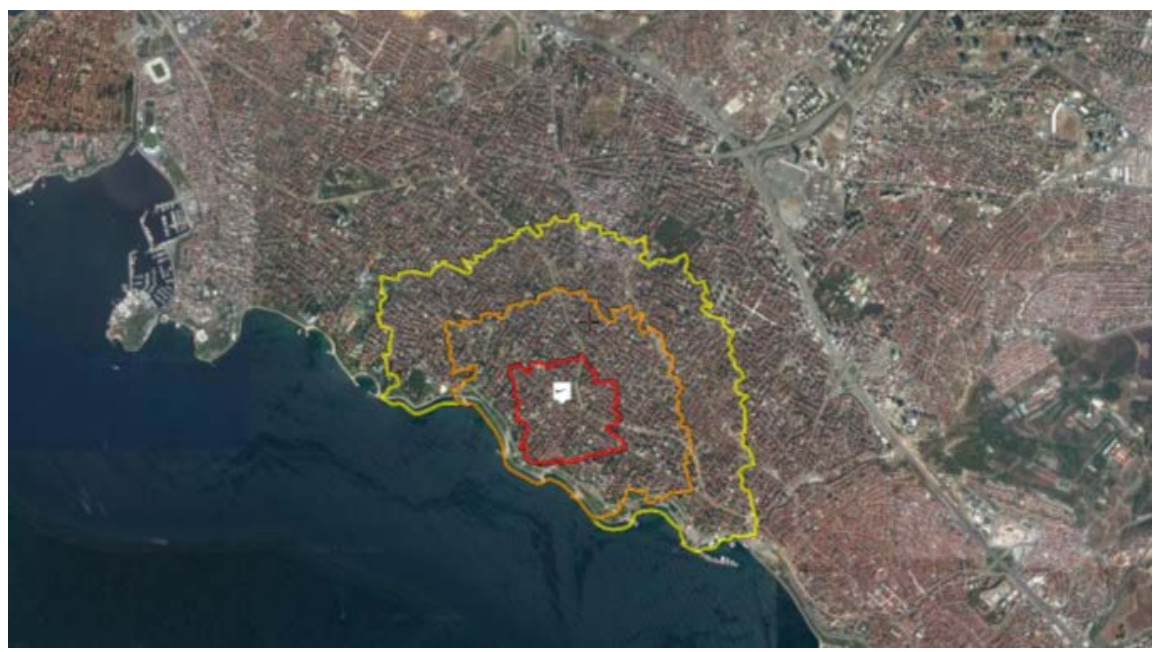

Figure 4. Travel distances of 10 (red), 20 (orange) and 30 minutes (yellow) by walking for the chosen store. 
The correlations between findings of the research analyzed by correlation analysis are as in Table 6.

As can be seen in Table 6, no significant correlation is found between the given factors. Only the correlation between store visit frequency and if the customers will visit the store again in 6 months when needed seems to be relatively stronger, but there is a negative correlation between the two questions. When the table is examined, it can be seen that customers do not have particular reasons for shopping; it is proven by the correlations between store visit frequency and other questions. Similar cases are seen in the results of gym/fitness center surveys (Table 7).

The strongest correlation in gym/fitness correlation table is the one between the location customers come from to the center and the location customers will go after the center. It can be stated that customers come to the center from their homes and they go back their homes after the center. This correlation is positive.

Table 6. Sports stores surveys correlation analysis.

\begin{tabular}{|c|c|c|c|c|c|}
\hline Relation & Type & Coefficient & Strength & $\begin{array}{c}\text { Sig. } \\
(2 \text { tailed })\end{array}$ & Reliability \\
\hline Age-Store visit frequency & + & 0.048 & Very poor & 0.298 & Not reliable \\
\hline Age-Transportation vehicle & + & 0.042 & Very poor & 0.368 & Not reliable \\
\hline $\begin{array}{l}\text { Reason to choose store- } \\
\text { Store visit frequency }\end{array}$ & - & 0.07 & Very poor & 0.13 & Not reliable \\
\hline $\begin{array}{l}\text { Reason to choose store- } \\
\text { Transportation vehicle }\end{array}$ & + & 0.145 & Very poor & 0.002 & Very reliable \\
\hline $\begin{array}{l}\text { Store visit frequency- } \\
\text { If they visit store again in } 6 \text { months }\end{array}$ & - & 0.425 & Poor & 0.000 & Very reliable \\
\hline $\begin{array}{c}\text { Store visit frequency- } \\
\text { Location they come from }\end{array}$ & - & 0.024 & Very poor & 0.602 & Not reliable \\
\hline $\begin{array}{l}\text { Store visit frequency- } \\
\text { Location they go to }\end{array}$ & - & 0.047 & Very poor & 0.31 & Not reliable \\
\hline $\begin{array}{l}\text { Store visit frequency- } \\
\text { Transportation vehicle }\end{array}$ & + & 0.122 & Very poor & 0.009 & Very reliable \\
\hline $\begin{array}{l}\text { Store visit frequency- } \\
\text { Monthly income }\end{array}$ & - & 0.106 & Very poor & 0.022 & Reliable \\
\hline $\begin{array}{l}\text { Time spent to reach store- } \\
\text { Location they come from }\end{array}$ & - & 0.18 & Very poor & 0.000 & Very reliable \\
\hline $\begin{array}{l}\text { Time spent to reach store- } \\
\text { Transportation vehicle }\end{array}$ & - & 0.08 & Very poor & 0.085 & Not reliable \\
\hline $\begin{array}{l}\text { If they visit store again in } \\
6 \text { months-Monthly income }\end{array}$ & - & 0.066 & Very poor & 0.157 & Not reliable \\
\hline $\begin{array}{l}\text { Monthly income- } \\
\text { Time spent to reach store }\end{array}$ & - & 0.021 & Very poor & 0.658 & Not reliable \\
\hline
\end{tabular}


Table 7. Gym/fitness center surveys correlation analysis.

\begin{tabular}{|c|c|c|c|c|c|}
\hline Relation & Type & Coefficient & Strength & $\begin{array}{l}\text { Sig. } \\
(2 \text { tailed })\end{array}$ & Reliability \\
\hline Age-Reason to choose center & - & 0.282 & Very poor & 0.000 & Very reliable \\
\hline Age-Center visit frequency & - & 0.056 & Very poor & 0.288 & Not reliable \\
\hline Age-Transportation vehicle & - & 0.164 & Very poor & 0.002 & Very reliable \\
\hline $\begin{array}{l}\text { Reason to choose center- } \\
\text { Time spent to reach center }\end{array}$ & + & 0.118 & Very poor & 0.025 & Reliable \\
\hline $\begin{array}{l}\text { Reason to choose center- } \\
\text { Location they come from }\end{array}$ & - & 0.131 & Very poor & 0.013 & Reliable \\
\hline $\begin{array}{l}\text { Center visit frequency- } \\
\text { Time spent to reach center }\end{array}$ & + & 0.074 & Very poor & 0.159 & Not reliable \\
\hline $\begin{array}{l}\text { Center visit frequency- } \\
\text { Transportation vehicle }\end{array}$ & + & 0.113 & Very poor & 0.033 & Reliable \\
\hline $\begin{array}{c}\text { Center visit frequency- } \\
\text { Monthly income }\end{array}$ & - & 0.175 & Very poor & 0.001 & Very reliable \\
\hline $\begin{array}{l}\text { Time spent to reach center- } \\
\text { Location they come from }\end{array}$ & + & 0.175 & Very poor & 0.001 & Very reliable \\
\hline $\begin{array}{l}\text { Time spent to reach center- } \\
\text { Transportation vehicle }\end{array}$ & - & 0.24 & Very poor & 0.000 & Very reliable \\
\hline $\begin{array}{l}\text { Location they come from- } \\
\text { Location they will go to }\end{array}$ & + & 0.439 & Poor & 0.000 & Very reliable \\
\hline $\begin{array}{l}\text { Transportation vehicle- } \\
\text { Monthly income }\end{array}$ & - & 0.013 & Very poor & 0.81 & Not reliable \\
\hline
\end{tabular}

Table 8. Store employee surveys correlation analysis.

\begin{tabular}{ccccccc}
\hline Relation & Type Coefficient & Strength & $\begin{array}{c}\text { Sig. } \\
\text { (2 tailed) }\end{array}$ & Reliability \\
\hline Location choice-Satisfaction & - & 0.008 & Very poor & 0.968 & Not reliable \\
Location choice-Customer profile & + & 0.851 & Strong & 0.000 & Very reliable \\
$\begin{array}{c}\text { Satisfaction-Desire to change location } \\
\text { Satisfaction-Customer profile }\end{array}$ & - & 0.958 & Very strong & 0.000 & Very reliable \\
Satisfaction-Mall/Street & + & 0.069 & Very poor & 0.731 & Not reliable \\
Customer profile-Mall/Street & - & 0.125 & Very poor & 0.534 & Not reliable \\
\hline
\end{tabular}

When we take a look at the store employee survey results through correlation analysis, we come across with stronger correlations. The correlation between the choice of location and customer profile seems to be a positive strong correlation. That is, the locations with a higher customer profile are suitable for opening stores. Another strong correlation seems to be the negative correlation between satisfaction from the location and desire to change the location, which suggests that the higher the satisfaction from the location, the lower is the desire to change the location (Table 8). 


\section{Conclusion}

Site selection has been one of the most important notions for commerce ever since the time it emerged. It is crucial for a retail store to choose the right location to survive and be successful in the market. The aim of this study is to examine the location selection criteria for sports retail sector, to identify how these criteria affect the success of the sector, how suitable these criteria are for Turkey, and to put forward suggestions about the topic. In this scope, surveys and fields studies are conducted and the obtained data are examined based on site selection methods and theories to reach the desired result.

Most retail companies nowadays show a tendency towards locations where they can reach the highest number of customers and turnover during the decision-making process for site selection. To put it shortly, it can be stated that retail companies consider financial issues the most during the site selection process. Moreover, companies can specify factors to achieve the targeted turnover and customers according to their structure and products. They choose the most suitable location meeting all their demands and criteria. Thus, we can state that companies benefit from cost analysis, comparison of factors and at par analysis methods from site selection methods.

In big cities of Turkey, customers who go to sports retail stores for shopping purposes usually leave their homes with the purpose of buying multiple goods. For this reason, they prefer shopping places where they can find many different products. This is one of the main reasons for malls to be preferred for shopping in big cities. Also, in malls customers can have a cup of coffee and take a rest when they are tired of shopping, can eat or do other activities with their children. As they offer a living space where different places and activities are integrated, malls are referred to as "shopping and life centers". Most of the customers can spend the whole day in malls with these activities and different places. And as has been suggested before, private car users prefer shopping malls as they have no parking problems. Thus, site selection of retail companies can be connected with multipurpose shopping and retail agglomeration and, spatial interaction and competing destinations theories.

According to the results of the surveys, product quality and range are the main reasons for customers to choose a store. For such concerns as product quality and range, customers can travel distances that are more than 30 minutes away and they prefer to travel in their private cars. This plays a great role for malls to be preferred as shopping places. The responses of store employees to the survey also provide support for these facts suggesting that customers choose malls for shopping and so they choose to have stores in malls.

Considering the fact that most of the companies in the sector are closing down their street stores and companies that have a stand-alone concept tend to open stores in malls, it can be stated that sports retail sector has started to focus on investing in malls. Opportunities that malls provide, customer attraction power, and easy access attract sports retail sector to malls as well. Customer 
crowd in malls especially on weekends and their cosmopolitan nature are also among the reasons why sports retail sector is attracted to malls. For local and foreign, new and existing investors alike, it can be suggested that in Turkeyespecially in Istanbul - they should channel their investments into malls.

\section{Acknowledgements}

This article is developed from the doctoral thesis of Tolga Kayacan, entitled as "Site Selection Criteria for Sports Retail Sector: Istanbul Case", prepared in Istanbul Technical University with the counseling of Prof. Dr. Funda Yirmibeşoğlu.

\section{References}

AT Kearney (2011). The Sports Market. Sector Report Paper, Korea.

Can, Y., Soyer, F., \& Güven, H. (2000). Evaluation of Factors Effecting Productivity in Sports Services, Statements, Volume II. Psycho-Social Fields in Sports, Sports Management Sciences. 1st Gazi Congress of Gym and Sports Sciences, Ankara, 26-27 May 2000, 182-200.

Cemalcılar, İ., Bayar, D., Aşkun, İ. C., \& Özalp, Ş. (1976). Business Management Info, Eskişehir Academy of Economic and Commercial Sciences Publication, No. 122, p. 48, Eskişehir.

Çambel, C. (2016). The Momentum of Sports Retailing Is Increasing. Retail Türkiye, July 2016, Volume 89.

Devecioğlu, S. (2005). Development of Sports Retail Sector Strategies in Turkey. Verimlilik Journal, 2, 117-134.

Glatte, T. (2015). Location Strategies: Methods and Their Methodological Limitations. Journal for Engineering, Design and Technology, 13, 435-462. https://doi.org/10.1108/JEDT-01-2013-0004

Goette, T. (1994). Location Policy of International Business. Wiesbaden: German University Publishers, XXVI.

Kayacan, T. (2017). Site Selection Criteria for Sports Retail Sector: Ístanbul Case. PhD Thesis, Istanbul: Istanbul Technical University.

Tesch, P. (1980). The Main Reasons for International Trade and Direct Investment. Berlin: Duncker and Humblot.

Url-1. (2016). http://www.ekonomist.com.tr/perakende/spor-perakendesinde-magazalasma-atagi.html

Uygun, Y. (1990). A Research on Site Selection Criterias of Touristic Enterprises. Master Thesis, Istanbul: Istanbul University. 
Submit or recommend next manuscript to SCIRP and we will provide best service for you:

Accepting pre-submission inquiries through Email, Facebook, LinkedIn, Twitter, etc. A wide selection of journals (inclusive of 9 subjects, more than 200 journals)

Providing 24-hour high-quality service

User-friendly online submission system

Fair and swift peer-review system

Efficient typesetting and proofreading procedure

Display of the result of downloads and visits, as well as the number of cited articles Maximum dissemination of your research work

Submit your manuscript at: http://papersubmission.scirp.org/

Or contact cus@scirp.org 